\title{
PELAKSANAAN STANDAR PENGELOLAAN PENDIDIKAN DI SEKOLAH DASAR KECAMATAN NGEMPLAK KABUPATEN SLEMAN
}

\author{
Mugi Rahayu \\ Dinas Pendidikan Pemuda dan Olahraga Kabupaten Sleman \\ Email: mugirahayu01@yahoo.com
}

\begin{abstract}
Abstrak
Penelitian ini bertujuan untuk mengetahui perencanaan, pelaksanaan, pengawasan dan evaluasi, kepemimpinan sekolah dasar, dan sistem informasi manajemen pendidikan dasar di sekolah dasar se-Kecamatan Ngemplak, Kabupaten Sleman, Yogyakarta. Pengambilan data dengan menggunakan angket yang ditujukan kepada kepala sekolah dan guru. Analisis data dilakukan secara kuantitatif deskriptif. Hasil penelitian menunjukkan: pertama, pelaksanaan pengelolaan pendidikan pada aspek perencanaan program pendidikan telah memenuhi standar pengelolaan hingga 98\%. Kedua, pelaksanaan pengelolaan pendidikan di Sekolah Dasar telah memenuhi standar pengelolaan hingga mencapai tingkat 96\%. Ketiga, pelaksanaan pengelolaan pendidikan di Sekolah Dasar pada aspek pengawasan pendidikan telah memenuhi standar pengelolaan hingga mencapai tingkat 91\%. Keempat, pelaksanaan pengelolaan pendidikan di Sekolah Dasar pada aspek kepemimpinan sekolah dasar telah memenuhi standar pengelolaan hingga mencapai tingkat 94\%. Kelima, pelaksanaan pengelolaan pendidikan di Sekolah Dasar di Kecamatan Ngemplak pada aspek sistem informasi manajemen telah memenuhi standar pengelolaan hingga mencapai tingkat $82,55 \%$.
\end{abstract}

Kata kunci: standar pengelolaan, Sekolah Dasar

\section{THE IMPLEMENTATION OF EDUCATION MANAGEMENT STANDARD IN PRIMARY SCHOOLS IN NGEMPLAK DISTRICT, SLEMAN REGENCY}

\begin{abstract}
This study aims to determine the planning, implementation, monitoring and evaluation, leadership elementary school, and elementary education management information system in a primary school Ngemplak District, Sleman District, Yogyakarta. Data collection using a questionnaire addressed to school principals and teachers. Quantitative data were analyzed descriptively. The results showed: first, the implementation of the management of education in all aspects of planning education program meets the standards and management of up to $98 \%$. Second, the implementation of management education in elementary school has met the management to achieve the level of $96 \%$. Third, the implementation of management education in primary school education on aspects of monitoring compliance with management standards up to the level of $91 \%$. Fourth, the implementation of management education in elementary schools on aspects of elementary school leadership has met the standard management until it reaches the level of $94 \%$. Fifth, the implementation of management education in an elementary school in the District Ngemplak on aspects of management information systems in compliance with management standards up to the level of $82.55 \%$.
\end{abstract}

Keywords: management standards, elementary school 


\section{PENDAHULUAN}

Pendidikan pada hakekatnya adalah usaha sadar dan terencana untuk mewujudkan suasana belajar dan proses pembelajaran agar peserta didik secara aktif mengembangkan potensi dirinya untuk memiliki kekuatan spiritual keagamaan, pengendalian diri, kepribadian, kecerdasan, ahklak mulia, serta keterampilan yang diperlukan dirinya, masyarakat, bangsa dan negara. Fungsi pendidikan sangat mungkin dijalankan karena proses mendidik merupakan cerminan manusia berbudaya. Manusia adalah homo sapiens yaitu makhluk yang memiliki akal budi, animal rational yaitu makhluk yang memiliki kemampuan berpikir, homo laquen yaitu makhluk yang mempunyai kemampuan berbahasa, homo faber atau homor toolmaking animal yaitu makhluk yang mampu membuat perangkat peralatan (Jalaluddin, 2011:77). Artinya manusia memiliki kebutuhan dan kemampuan untuk menjadikan masyarakatnya lebih berbudaya. Fungsi dan tujuan pendidikan nasional tercantum dalam UU No. 20 tahun 2003 bab II pasal 3. Fungsi pendidikan nasional adalah mengembangkan kemampuan dan membentuk watak serta peradaban bangsa yang bermartabat dalam rangka mencerdaskan kehidupan bangsa. Tujuan pendidikan nasional adalah untuk mengembangkan potensi-potensi peserta didik yang menjadi manusia beriman dan bertaqwa kepada Tuhan Yang Maha Esa, berakhlak mulia, sehat, berilmu, cakap, kreatif, mandiri dan menjadi warga negara yang demokratis serta bertanggung jawab. Fungsi dan tujuan pendidikan nasional dalam rumusan tersebut merupakan proses memuliakan manusia agar berkembang sesuai dengan potensi kebaikan yang dimilikinya.

Peraturan Pemerintah (PP) Republik Indonesia Nomor 19 Tahun 2005 tentang Standar Nasional Pendidikan (SNP) mengamanatkan bahwa setiap satuan pendidikan pada jenjang pendidikan dasar dan menengah harus menyusun kuriku- lum dengan mengacu kepada Standar Isi, Standar Kompetensi Lulusan, Standar Pengelolaan Pendidikan, Standar Proses, dan Standar Penilaian, serta berpedoman pada panduan yang disusun oleh Badan Standar Nasional Pendidikan. Standar pengelolaan pendidikan adalah standar dalam mengelola pendidikan dalam satu lembaga pendidikan. Dalam standar ini, pendidikan dikelola oleh satuan pendidikan, pemerintah daerah, dan pemerintah. Menurut Permendiknas No.19 tahun 2007 ada enam hal yang harus diperhatikan dalam pengelolaan pendidikan yang dilaksanakan di satuan pendidikan dasar dan menengah. Enam hal tersebut yaitu: Perencanaan program, pelaksanaan program, pengawasan dan evaluasi program, kepemimpinan sekolah, sistem informasi manajemen, dan penilaian khusus. Pengelolaan membutuhkan adanya pelaksanaan dari seluruh fungsi-fungsi manajemen dalam penyelenggaraan pendidikan, meliputi planning, organizing, actuating dan controlling (Nanang Fatah, 2004:1).

Perencanaan yang baik hendaknya memperhatikan karakteristik kondisi yang akan datang yang diharapkan (Nanang Fattah, 2004:49). Perencanaan adalah pembuatan keputusan, proses pengembangan dan penyeleksian sekumpulan kegiatan untuk memecahkan masalah tertentu (Hani Handoko, 2003:77). Keputusan merupakan tindakan memilih berdasarkan pada informasi. Informasi yang didapat harus dapat menjadi dasar bagi empat pertanyaan yang harus terjawab dalam perencanaan yaitu 1) di mana keadaan sekarang (where are we now?) untuk menilai kondisi internal dan eksternal organisasi; 2) di mana keadaan yang kita inginkan (where do we want to be?) untuk mengarahkan semua sumber daya secara efisien; 3) bagaimana kita menuju dari kondisi sekarang ke kondisi yang kita inginkan (how do we get from here to there?) untuk menentukan pilihan tindakan atau upaya yang dibutuhkan; 4) bagaimana kita melakukannya? apakah sudah sampai?

Pelaksanaan Standar Pengelolaan Pendidikan di Sekolah Dasar Kecamatan Ngemplak ... 
(how did we do? where are we now?) sebagai dasar untuk melakukan evaluasi (Boudreau, 1997:142).

Pengorganisasian merupakan proses penyusunan organisasi yang sesuai dengan tujuan organisasi, sumber daya yang dimilikinya, dan lingkungan yang melingkupinya (Hani Handoko, 2003:167). Penggerakan atau pengarahan (actuating) merupakan fungsi manajemen yang terpenting dan paling dominan dalam proses manajemen. Fungsi ini baru diterapkan setelah rencana, organisasi dan karyawan ada. Jika fungsi ini diterapkan maka proses manajemen dalam merealisasi tujuan dimulai. Hani Handoko (2003:25) menjelaskan bahwa fungsi pengarahan adalah menjadikan para karyawan melakukan apa yang diinginkan dan harus mereka lakukan.

Pengorganisasian dan pengarahan tercermin pada pelaksanaan Rencana Kerja Sekolah/Madrasah. Pelaksanaan meliputi seluruh bidang pelaksanaan operasional sekolah, meliputi: bidang kesiswaan, kurikulum dan kegiatan pembelajaran, pendidik dan tenaga kependidikan, sarana dan prasarana, keuangan dan pembiayaan, budaya dan lingkungan sekitar serta peran serta masyarakat dan kemitraan sekolah. Seluruh bidang tersebut diselenggarakan dan dikelola oleh satuan pendidikan yang dibentuk dalam struktur organisasi sekolah/madrasah. Struktur organisasi sekolah terdiri dari: semua pimpinan, pendidik, dan tenaga kependidikan yang mempunyai uraian tugas, wewenang, dan tanggung jawab yang jelas tentang keseluruhan penyelenggaraan dan administrasi sekolah.

Pelaksanaan rencana kerja/kegiatan sekolah dilaksanakan berdasarkan rencana kerja tahunan oleh penanggung jawab kegiatan. Berikut ini beberapa pelaksanaan kegiatan sekolah yang dilaksanakan berdasarkan bidang garapannya, meliputi:

1) Bidang Kesiswaan

Bidang kesiswaan melakukan pengelolaan meliputi: a) Menetapkan petunjuk pelaksanaan operasional mengenai proses penerimaan peserta didik; $b$ ) Memberikan layanan konseling kepada peserta didik; c) Melaksanakan kegiatan ekstra dan nonkurikuler untuk para peserta didik; d) Melakukan pembinaan prestasi unggulan; e) Melakukan pelacakan terhadap alumni.

2) Bidang Kurikulum dan Kegiatan Pembelajaran

Pelaksanaan program di bidang ini meliputi: a) Menyusun KTSP dan jadwal berdasarkan kalender pendidikan; b) Menyusun dan mengembangkan program pembelajaran berdasarkan standar kompetensi dan kompetensi dasar yang ditetapkan. c) Menyusun program penilaian hasil belajar peserta didik; d) Menyusun dan menetapkan peraturan akademik.

3) Bidang Pendidik dan Tenaga Kependidikan

Pelaksanaan program di bidang ini meliputi: a) Menyusun program pendayagunaan pendidik dan tenaga kependidikan, dan b) Mengangkat pendidik dan tenaga kependidikan tambahan yang dilaksanakan berdasarkan ketentuan yang telah ditetapkan oleh penyelenggara sekolah.

4) Bidang Sarana dan Prasarana

Pelaksanaan program di bidang ini meliputi: a) Menetapkan kebijakan program secara terttulis mengenai pengelolaan sarana dan prasarana; $b$ ) Merencanakan, mengadakan, memelihara sarana dan prasarana yang ada di sekolah; c) Menyusun skala prioritas pengembangan fasilitas pendidikan sesuai dengan tujuan pendidikan dan kurikulum.

5) Bidang Keuangan dan Pembiayaan Pelaksanaan program di bidang ini yaitu menyusun pedoman pengelolaan biaya investasi dan operasional yang mengacu pada standar pembiayaan. 
6) Bidang Budaya dan Lingkungan Sekolah

Pelaksanaan program di bidang ini meliputi: a) Menciptakan suasana, iklim, dan lingkungan pendidikan yang kondusif untuk pembelajaran yang efisien dalam prosedur pelaksanaan; b) Menetapkan pedoman tata tertib/ peraturan sekolah; c) Menetapkan kode etik warga sekolah.

7) Bidang Humas/Peran serta Masyarakat dan Kemitraan Sekolah

Program di bidang ini dilaksanakan dengan cara sekolah menjalin kemitraan dan kerja sama dengan masyarakat dan lembaga lain untuk mendukung program pelaksanaan kegiatan sekolah dalam rangka pengelolaan pendidikan.

Controlling atau pengendalian adalah pengukuran dan perbaikan terhadap pelaksanaan kerja bawahan, agar rencanarencana yang telah dibuat untuk mencapai tujuan-tujuan dapat terselenggara (Hasibuan, 2006:241). Perencanaan, pengorganisasian, pengarahan, dan pengendalian sumber daya organisasi sebagai suatu sistem yang terintegrasi (Husaini Usman, 2006:2).

Pengendalian atau pengawasan merupakan proses kegiatan monitoring untuk meyakinkan bahwa semua kegiatan organisasi terlaksana seperti yang direncanakan dan sekaligus juga merupakan kegiatan untuk mengoreksi dan memperbaiki bila ditemukan adanya penyimpangan yang akan mengganggu pencapaian tujuan. Pengawasan merupakan proses menjamin terpenuhinya kualitas seperti yang diharapkan. Kualitas diketahui melalui hasil audit dan pengukuran yang dapat dipertanggungjawabkan. Pengawasan merupakan mekanisme untuk menjamin tercapainya kualitas, seperti dalam bentuk akreditasi oleh pihak pemerintah atau pihak eksternal (Becket dan Brookes, 2008:41).
Sekolah harus objektif, bertanggung jawab dan berkelanjutan dalam melakukan pengawasan. Pengawasan meliputi pemantauan, supervisi, evaluasi, pelaporan dan tindak lanjut hasil pengawasan. Pemantauan dilakukan oleh komite sekolah, sedangkan supervisi dilakukan secara teratur dilakukan oleh kepala sekolah. Guru melaporkan hasil evaluasi dan penilaian sekurang-kurangnya kepada kepala sekolah.

Setiap pihak yang menerima laporan hasil pengawasan harus menindaklanjuti setiap laporan yang diterimanya dan menggunakan hasil pemantauan atau pengawasan tersebut untuk memperbaiki kinerja sekolah dan sebagai sarana pendidikan. Program Evaluasi dapat dilaksanakan dengan menggunakan jenis-jenis evaluasi yang sesuai dengan maksud dan tujuan evaluasi. Jenis-jenis evaluasi yang dapat digunakan yaitu:

1) Evaluasi diri adalah evaluasi yang dilakukan pihak sekolah untuk menilai kinerja sekolah itu sendiri. Pihak sekolah menetapkan prioritas indikator untuk mengukur, menilai kinerja dan melakukan perbaikan dalam rangka pelaksaaan Standar Nasional Pendidikan. Evaluasi diri atau evaluasi sekolah dilakukan secara periodik berdasarkan pada data dan informasi yang sahih

2) Evaluasi dan pengembangan KTSP adalah proses yang dilakukan secara komprehensif dan flexible agar bisa menghadapi kemajuan ilmu pengetahuan dan teknologi yang mutakhir dan bersifat menyeluruh yang artinya melibatkan semua pihak.

3) Evaluasi pendayagunaan pendidik dan tenaga pendidik meliputi kesesuaian penugasan dengan keahlian, keseimbangan beban kerja dan kinerja pendidik dan tenaga kependidikan dalam pelaksaan tugas. Evaluasi harus memperhatikan pencapaian prestasi dan perubahan perubahan peserta didik. 
Griffin dan Nix (Djemari Mardapi, 2008:1) mengemukakan pengertian evaluasi ke dalam tiga bagian yaitu pengukuran, asesmen dan evaluasi. Pengukuran membandingkan hasil pengamatan dengan kriteria, asesmen menjelaskan dan menafsirkan hasil pengukuran, sedangkan evaluasi adalah menetapkan nilai atau implikasi dari suatu perilaku. Dengan demikian, setiap evaluasi pasti melibatkan pengukuran dan asesmen.

Salah satu aspek yang dievaluasi dalam penyelenggaraan pendidikan adalah evaluasi pembelajaran. Evaluasi pembelajaran bertujuan untuk mengetahui efektifitas dan efisiensi sistem pembelajaran baik menyangkut tujuan, materi, metode, media, sumber belajar, lingkungan belajar serta sistem penilaian dalam pembelajaran. Dalam konteks memberikan pendidikan kepada peserta didik, evaluasi bertujuan untuk mengetahui tingkat pengetahuan, keterampilan, sikap dan nilai-nilai peserta didik untuk jenis pendidikan tertentu (Zaenal Arifin, 2009:14).

Fungsi evaluasi pembelajaran adalah: pertama, sebagai perbaikan dan pengembangan sistem pembelajaran. Sistem pembelajaran meliputi tujuan, materi, metoda, media, sumber belajar, lingkungan, guru dan peserta. Kedua, untuk akreditasi sebagaimana ditegaskan dalam UU No 20 tahun 2003 tentang Sistem Pendidikan Nasional bahwa akreditasi adalah kegiatan penilaian kelayakan program dalam satuan pendidikan berdasarkan kriteria yang telah ditetapkan (Zaenal Arifin, 2009:20).

Fungsi evaluasi terkait dengan tujuan evaluasi yaitu untuk mendapatkan data tentang pencapaian tujuan-tujuan kurikuler. Secara rinci, fungsi evaluasi menurut Ngalim Purwanto (2010:5) ada empat, yaitu:

1) Untuk mengetahui kemajuan dan perkembangan serta hasil belajar siswa setelah belajar dalam jangka waktu tertentu.
2) Untuk mengetahui tingkat keberhasilan program pengajaran.

3) Untuk memberikan informasi atau data bagi pelayanan bimbingan dan konseling oleh guru BK.

4) Untuk keperluan pengembangan dan perbaikan kurikulum sekolah yang bersangkutan.

Selain standarisasi dalam hal evaluasi, standarisasi dalam aspek kepemimpinan juga dilakukan. Kepemimpinan adalah kemampuan seseorang (pemimpin) untuk mempengaruhi orang lain sehingga orang yang dipengaruhi bertingkah laku seperti yang dikehendaki oleh pemimpin. Kepemimpinan ada yang bersifat resmi (formal leadership) ada pula yang tidak resmi (informal leadership). Kemunculan seorang pemimpin merupakan hasil dari proses dinamis memenuhi kebutuhankebutuhan kelompok (Soerjono Soekanto, 2002:280). Kepemimpinan merupakan suatu kegiatan untuk mempengaruhi perilaku orang-orang agar bekerjasama menuju kepada suatu tujuan tertentu yang mereka inginkan bersama.

Pengertian kepemimpinan tampak dalam proses seseorang ketika memimpin, membimbing, mempengaruhi atau mengendalikan pikiran, perasaan, atau tingkah laku orang lain. Kegiatan tersebut dapat dilakukan melalui berbagai bentuk baik karya, kegiatan atau melalui kontak personal secara tatap muka. Faktor penting dalam kepemimpinan, yakni dalam mempengaruhi atau mengendalikan pikiran, perasaan, atau tingkah laku orang lain adalah tujuan dan rencana. Namun demikian tidak selalu kepemimpinan merupakan kegiatan yang direncanakan dan dilakukan dengan sengaja, seringkali juga kepemimpinan berlangsung secara spontan. Fungsi kepemimpinan secara praktis beserta gaya kepemimpinannya akan berbeda menurut situasi di mana pemimpin itu melakukan kegiatannya. Kepemimpinan biasanya berada dalam satu struktur kelompok karena harus da- 
pat mewakili fungsi administratif eksekutif yang meliputi koordinasi dan integrasi atas berbagai aktivitas dalam kelompok atau orang-orang yang terlibat di dalam kepemimpinan tersebut (Muksin Wijaya, 2005:120).

Hubungan antara pemimpin dengan orang yang dipimpinnya memunculkan gaya pemimpin dalam menjalankan fungsi kepemimpinannya. Husaini Usman (2006:314) yang menyatakan bahwa gaya kepemimpinan adalah pola tingkah laku yang ditampilkan ketika mencoba mempengaruhi tingkah laku orang lain seperti yang dipersepsikan oleh orang yang akan kita pengaruhi tersebut. Kepemimpinan ini didasarkan saling pengaruh antara perilaku kepemimpinan yang ia terapkan, sejumlah pendukungan emosional yang ia berikan, dan tingkat kematangan bawahannya.

Dalam kepemimpinan terdapat bermacam-macam gaya kepemimpinan dengan masing-masing keterbatasan dan kelebihannya. Berikut beberapa gaya kepemimpinan yang kerap kita lihat atau alami saat ini: a. Kediktatoran, gaya kepemimpinan kediktatoran cenderung mempertahankan diri atas kekuasaan dan kewenangannya dalam pembuatan keputusan, b. Demokrasi relatif, gaya kepemimpinan ini lebih lunak dari gaya kediktatoran, dan kepemimpinan ini berusaha memastikan bahwa kelompoknya mendapatkan informasi memadai dan berpartisipasi dalam tujuan tim sebagai satu entitas, c. Kemitraan, gaya kepemimpinan ini mengaburkan batas antara pemimpin dan para anggotanya, dengan suatu kesejajaran dan berbagi tanggung jawab, $\mathrm{d}$. Transformasional, gaya kepemimpinan yang mampu mendatangkan perubahan di dalam diri setiap individu yang terlibat dan/atau bagi seluruh organisasi untuk mencapai kinerja yang semakin tinggi.

Penerapan kepemimpinan dipengaruhi oleh situasi kerja atau bawahan dan sumber daya pendukung organisasi. De- ngan demikian kepemimpinan di perusahaan mencari profit akan berbeda dengan kepemimpinan di perusahaan non profit seperti di lembaga pendidikan atau di sekolah (Wahyudi, 2009:120). Kepemimpinan di sekolah harus memiliki TEKNIK, yaitu 1) Terampil, memiliki, 2) Etos kerja, 3) Keberanian, 4) Negosiasi, 5) Intuisi bisnis, 6) Kewirausahaan (Husaini Usman, 2006:316-318). Berbagai komponen teknik tersebut dibutuhkan dalam mengelola sekolah.

Harris dan Spillane (2008:32) mengemukakan bahwa pengelolaan sekolah membutuhkan adanya kolaborasi, jaringan kerjasama dan peran dari berbagai pihak sehingga kepemimpinan di sekolah membutuhkan suatu pola kepemimpinan yang didistribusikan. Dalam hal ini, kepala sekolah lebih menekankan pada membangun interaksi formal dan informal secara intens kepada semua pihak sehingga setiap pihak merasa memiliki kemampuan dan pada saat yang sama dapat digerakkan oleh pemimpin (kepala sekolah).

Bush (2007:392) menjelaskan bahwa kepemimpinan merupakan tindakan-tindakan mempengaruhi orang lain guna mencapai tujuan akhir. Pemimpin merupakan orang yang menentukan tujuan yang ingin dicapai, membentuk motivasi dan menentukan tindakan-tindakan orang lain dengan menggunakan kekuatan, keahlian dan karakter yang dimilikinya. Kepemimpian yang baik membutuhkan kemampuan manajeman yang baik pula karena manajemen dibutuhkan untuk menjadikan organisasi berjalan efektif dan efisien.

Upaya meningkatkan mutu pendidikan melalui standarisasi pengelolaan pendidikan dasar membutuhkan kesanggupan semua pihak untuk melakukan perubahan. Dalam hal ini kepala sekolah harus dapat memimpin perubahan tersebut dengan mengajak semua warga sekolah untuk belajar kembali bagaimana mengelola pendidikan. Kepala sekolah harus dapat 
menjaga agar tetap ada komitmen untuk melakukan perubahan, inovasi dan perbaikan. Sebagai manajer harus dapat mendesain struktur organisasi, dan membangun budaya organisasi (sekolah) yang terbuka, tumbuh dan berani ambil resiko (Robbind, S. dan Judge, T.A., 2007:593).

Tugas dan Kewajiban Pemimpin sekolah/madrasah: 1) Menjabarkan visi ke dalam misi target mutu yang akan dicapai; 2) Merumuskan tujuan dan target mutu yang akan dicapai; 3) Menganalisis tantangan, peluang, kekuatan dan kelemahan sekolah dan madrasah; 4) Membuat rencana kerja strategis dan rencana kerja tahunan untuk pelaksanaan peningkatan mutu; 5) Bertanggung jawab dalam membuat keputusan anggaran sekolah dan madrasah; 6) Melibatkan guru, komite sekolah dalam pengambilan keputusan penting sekolah/madrasah. Dalam hal ini sekolah / madrasah swasta, pengambilan keputusan tersebut harus melibatkan penyelenggara sekolah dan madrasah; 7) Berkomunikasi untuk menciptakan dukungan intensif dari orang tua peserta didikdan masyarakat; 8) Menjaga dan meningkatkan motivasi kerja pendidikan dan tenaga kependidikan dengan menggunakan sistem pemberian penghargaan atas prestasi dan sangsi atas pelanggaran peraturan dan kode etik; 9) Menciptakan lingkungan pembelajaran yang efektif bagi peserta didik

1) Bertanggungjwab atas perencanaan partisifatif mengenai pelaksanaan dan kurikulum

2) Melaksanakan dan merumuskan program supervise, serta memanfaatkan hasil supervise untuk meningkatkan kinerja sekolah dan madrasah

3) Meningkatkan mutu pendidikan

4) Memberi teladan dan menjaga nama baik lembaga, profesi dan kedudukan sesuai dengan kepercayaan yang diberikan kepadanya

5) Memfasilitasi pengembangan, penyebarluasan dan pelaksanaan visi pembelajaran yang dikomunikasikan dengan baik dan didukung oleh komunitas sekolah/madrasah

6) Membantu, membina dan mempertahankan lingkungan sekolah/madrasah dan progam pembelajaran yang kondusif bagi proses belajar peserta didik dan pertumbuhan profesional para guru dan tenaga kependidikan

7) Menjamin manajemen organisasi dan pengoperasian sumber daya sekolah/ madrasah untuk menciptakan lingkungan belajar yang aman, sehat efisien dan efektif

8) Menjalin kerjasama dengan orang tua peserta didik dan masyarakat dan komite sekolah / madrasah menanggapi kepentingan dan kebutuhan komunitas yang beragam dan memobilisasi sumber daya masyrakat

9) Memberi contoh/teladan/tindakan yang bertanggung jawab.

Aspek lainnya yang distandarisasi yaitu sistem informasi manajemen. Sistem Informasi Manajemen Pendidikan adalah suatu sistem yang dirancang untuk menyediakan dan mengambil keputusan pada kegiatan manajemen (perencanaan, Penggerakan, Pengorganisasian, dan pengedalian) dalam lembaga pendidikan (Eti Rohayati, 2005: 13). Tujuan dari Sistem Informasi Manajemen Pendidikan yang dikemukakan oleh Eti Rohayati (2005: 20) menyatakan bahwa:" menghasilkan informasi yang tepat waktu (timely) bagi manajemen tentang lingkungan ekternal dan operasi internal dan mendorong serta mempercepat proses Pengambilan keputusan baik pada saat perencanaan, Penggerakan, Pengorganisasian, dan pengendalian.

Adapun Jenis Sistem Informasi Manajemen Pendidikan ada tiga jenis sistem yang ditawarkan bagi Lembaga Pendidikan untuk Implementasikan IOS (Inter Organizational System), yaitu sebagaimana berikut (Eti Rohayati, 2005: 20): (1) Intranet, Jaringan Internal Lembaga Pendidikan yang menghubungkan antara kantor pusat 
dan kantor cabang yang terpisah secara geografis, baik lokasi maupun regional., (2) Internet, jaringan komputer publik yang berpotensi sebagai penghubung lembaga pendidikan dengan para pengguna program pendikan atau calon siswa atau mahasiswanya. (3) Ekstranet, jaringan yang dibangun sebagai alat komunikasi antar lembaga pendidikan dan lembaga pendukungnya, seperti departemen pendidikan, masyarakat, pemerintah, dan dunia usaha.

Pengelolaan standar informasi majamen sekolah tampak dari sejumlah indikator berikut (BNSP, 2007:38) :

1) Mengelola sistem informasi manajemen yang memadai untuk mendukung administrasi pendidikanyang efektif, efisien dan akuntabel.

2) Menyediakan fasilitas informasi yang efesien, efektif dan mudah diakses.

3) Menugaskan seorang guru atau tenaga kependidikan untuk melayani permintaan informasi maupun pemberian informasi atau pengaduan dari masyarakat berkaitan dengan pengelolaan sekolah/madrasah baik secara lisan maupun tertulis dan semuanya direkam dan didokumentasikan.

4) Melaporkan data informasi sekolah/ madrasah yang telah terdokumentasikan kepada Dinas Pendidikan Kabupaten/Kota.

Standarisasi pengelolaan pendidikan dilakukan karena pelaksanaan MBS, meskipun secara prinsipil memberikan otonomi kepada sekolah, tetapi tetap harus ada standar yang menjadi acuan dalam melakukan pengawasan terhadap jalananya pendidikan nasional. Manajemen Berbasis Sekolah yang biasa disingkat dengan MBS merupakan konsep school Based manajement (SBM). Caldwell (2005:1) menulis bahwa:

School-based management (SBM) is the systematic decentralization to the school level of authority and responsibility to make decisions on significant matters related to school operations within a centrally determined framework of goals, policies, curriculum, standards, and accountability.

School-based management biasanya dimulai dengan desentralisasi dan dilanjutkan dengan pelimpahan kekuasaan tertentu dari pusat ke sekolah yang dapat mencakup segala bentuk kekuasaan dari yang sebagian kecil, terbatas sampai kepada yang hampir semuanya.

Manajemen berbasis sekolah ini merupakan suatu model manajemen yang memberikan otonomi lebih besar kepada sekolah dan mendorong pengambilan keputusan partisipatif seluruh stakeholder untuk meningkatkan mutu sekolah berdasarkan kebijakan nasional. Berdasarkan pendapat di atas dapat dipahami bahwa MBS diartikan sebagai suatu bentuk desentralisasi yang memandang sekolah sebagai suatu unit dasar pengembangan dan bergantung pada redistribusi otoritas pengambilan keputusan.

Secara konseptual, MBS didefinisikan sebagai proses manajemen sekolah yang diarahkan pada peningkatan mutu pendidikan, secara otonomi direncanakan, diorganisasikan, dilaksanakan dan dievaluasi dengan melibatkan semua stakeholders. Secara operasional, MBS didefinisikan sebagai keseluruhan proses pendayagunaan seluruh komponen pendidikan dalam rangka peningkatan mutu pendidikan yang diupayakan sendiri oleh kepala sekolah bersama semua pihak yang terkait atau berkepentingan dengan mutu pendidikan.

Penerapan MBS secara yuridis diamanatkan oleh beberapa aturan perundangan antara lain: (a) Undang-Undang Republik Indonesia Nomor 20 Tahun 2003 tentang Sistem Pendidikan Nasional, Pasal 51, Ayat (1); "Pengelolaan satuan pendidikan anak usia dini, pendidikan dasar, dan pendidikan menengah dilaksanakan berdasarkan standar pelayanan minimal 
dengan prinsip manajemen berbasis sekolah/ madrasah" (b) Peraturan Pemerintah Republik Indonesia Nomor 19 Tahun 2005 tentang Standar Nasional Pendidikan, Pasal 49, Ayat (1); "Pengelolaan satuan pendidikan pada jenjang pendidikan dasar dan menengah menerapkan manajemen berbasis sekolah yang ditunjukkan dengan kemandirian, kemitraan, partisipasi, keterbukaan, dan akuntabilitas"; (c) Peraturan Menteri Pendidikan Nasional Nomor 19 Tahun 2007 tentang Standar Pengelolaan Pendidikan, yang akan diuraikan lebih mendetail lagi pada BAB II dan III; (d) Peraturan Pemerintah No 17 Tahun 2010 tentang Pengelolaan dan Penyelenggaraan Pendididikan, Pasal 50 dan 51. Pasal 50 "Satuan atau program pendidikan wajib bertanggung jawab mengelola sistem pendidikan nasional di satuan atau program pendidikannya serta merumuskan dan menetapkan kebijakan pendidikan sesuai dengan kewenangannya" (Darwis Sasmedi, 2008).

MBS dapat diartikan sebagai model pengelolaan yang memberikan otonomi (kewenangan dan tanggungjawab) lebih besar terhadap sekolah, memberikan fleksibilitas/keluwesan-keluwesan terhadap sekolah, dan mendorong partisipasi secara langsung warga sekolah (guru, siswa, kepala sekolah, karyawan) dan masyarakat (orangtua siswa, tokoh masyarakat, ilmuwan, pengusaha, dan sebagainya). Hal-hal tersebut dilakukan untuk meningkatkan mutu sekolah berdasarkan kebijakan pendidikan nasional serta peraturan perundang-undangan yang berlaku. Dengan otonomi tersebut, sekolah diberikan kewenangan dan tanggungjawab untuk mengambil keputusan-keputusan sesuai dengan kebutuhan, kemampuan dan tuntutan sekolah serta masyarakat atau stakeholder yang ada. MBS tidak dibenarkan menyimpang dari peraturan perundangundangan yang berlaku).

Target manajemen berbasis sekolah dirumuskan dalam permendiknas nomer
19 tahun 2007 tentang pengelolaan pendidikan, mencakup 6 target seperti berikut: (1) perencanaan program; (2) pelaksanaan rencana kerja; (3) pengawasan dan evaluasi; (4) kepemimpinan sekolah/madrasah; (6) sistem informasi manajemen; dan (7) penilaian khusus. Masing-masing target diuraikan lebih lanjut menjadi butir-butir target, misalnya komponen perencanaan program dibagi menjadi 4 butir yaitu visi, misi, tujuan dan rencana kerja sekolah. Untuk melakukan perumusan rencana kerja, sekolah perlu melakukan evaluasi diri sekolah, sebagaimana diatur dalam Permendiknas 19 tahun 2007 tentang pengelolaan sekolah, peraturan menteri Pendidikan Nasional Nomer 63 tahun 2009 tentang Sistim Penjaminan Mutu Pendidikan (Darwis Sasmedi, 2008).

Candoll (Umaedi, 2000) memandang MBS sebagai alat untuk mengambil tanggung jawab terhadap apa yang terjadi kepada anak-anak yang mengikuti pendidikan di sekolah. Dengan kata lain sekolah mempunyai kewenangan untuk mengembangkan partisipasi lingkungan di antara siswa dan staf, penggunaan waktu yang fleksibel, menciptakan kondisi sekolah yang kondusif, mengembangkan kurikulum yang berfokus kepada siswa dan kemampuan berfikir tinggi.

Manajemen pendidikan berbasis sekolah yang sedang dikembangkan di Indonesia lebih menekankan pada pemberian kewenangan, kepercayaan, dan kemandirian kepada sekolah untuk mengelola dan mengembangkan sumberdaya pendidikan dalam rangka meningkatkan mutu pendidikan di sekolah masing-masing serta mempertanggungjawabkan hasilnya kepada orang tua siswa, masyarakat, pemerintah dalam koridor kebijakan pendidikan nasional. Dengan demikian target utama MBS di Indonesia adalah pemberdayaan sekolah untuk secara mandiri dapat meningkatkan mutu pendidikan masingmasing. Oleh karena itu, kemampuan leadership dan manajemen sekolah dan keterse- 
diaan resources yang memadai merupakan persyaratan bagi keberhasilan pelaksanaan MBS ini (Umaedi 2000:78).

Manajemen berbasis sekolah (MBS) dapat diartikan Sebagai pengkoordinasian dan penyerasian sumber daya yang dilakukan secara mandiri oleh sekolah dengan melibatkan semua kelompok kepentingan terkait dengan sekolah atau "Stakeholders" secara langsung dalam proses pengambilan keputusan untuk memenuhi kebutuhan mutu sekolah atau untuk mencapai tujuan mutu sekolah dalam kerangka pendidikan nasional. MBS secara umum, dapat diartikan model manajemen yang memberikan otonomi lebih besar kepada sekolah dan mendorong pengambilan keputusan partisipatif yang melibatkan secara langsung semua warga sekolah (guru, siswa, kepala sekolah, karyawan, orangtua siswa, dan masyarakat untuk meningkatkan mutu sekolah berdasarkan kebijakan pendidikan nasional.

Proses pendidikan dalam kerangka MBS memiliki berbagai karakteristik, yaitu: (1) proses belajar dan mengajar dengan tingkat efektivitas tinggi, (2) kepempimpinan kepala sekolah yang kuat, (3) lingkungan sekolah yang aman dan tertib, (4) pengelolaan tenaga kependidikan yang efektif, (5) adanya budaya mutu, (6) adanya teamwork yang kompak, cerdas, dan dinamis, (7) adanya kemandirian, (8) partisipasi semua warga sekolah dan masyarakat, (9) keterbukaan manajemen, (10) memiliki kemauan untuk berubah, (11) adanya evaluasi dan perbaikan secara berkelanjutan, (12) sekolah responsif dan antisipatif terhadap kebutuhan, (13) memiliki komunikasi yang baik, (14) memiliki akuntabilitas dan mampu menjaga sustainabilitas (Mulyasa, 2004:90-94).

Berdasarkan paparan di atas dan beberapa pertimbangan bahwasanya pengelolaan pendidikan di sekolah dasar menjadi kunci secara mutlak untuk mencapai kualitas pendidikan, maka peneliti memandang perlu untuk melakukan penelitian tentang standar pengelolaan pendidikan di sekolah dasar. Penelitian ini bertujuan untuk mengetahui perencanaan, pelaksanaan, pengawasan dan evaluasi, kepemimpinan sekolah dasar, dan sistem Informasi Manajemen pendidikan dasar di sekolah dasar se Kecamatan Ngemplak, Kabupaten Sleman, Yogyakarta.

Berdasarkan studi pendahuluan di lokasi penelitian dapat diidentifikasi masalah-masalah sebagai berikut:

1. Mutu pendidikan di Indonesia masih rendah di bandingkan dengan negaranegara lain di Asia Tenggara.

2. Kesenjangan pendidikan masih terjadi antara satu daerah dengan daerah lain, antara satu sekolah dengan sekolah lainnya.

3. Implementasi standarisasi pendidikan dalam hal standar isi masih dihadapkan pada implementasi kurikulum yang tidak optimal.

4. Masih adanya keterbatasan kompetensi guru di sekolah

5. Standar kompetensi lulusan yang diukur dari hasil evaluasi berupa ujian nasional belum menggambarkan kompetensi lulusan yang diharapkan.

6. Pengelolaan pendidikan belum memperlihatkan kualitas pengelolaan yang sama dengan konsep standar pengelolaan pendidikan dan manajemen berbasis sekolah, terbukti dengan nilai akreditasi sekolah yang berbeda-beda. Penelitian ini tidak mengambil seluruh permasalahan yang ada seperti yang tertera pada identifikasi masalah, tetapi difokuskan pada identifikasi masalah yang terakhir, yakni ketidaksesuaian antara pelaksanaan pengelolaan pendidikan dengan konsep standar pengelolaan pendidikan dan manajemen berbasis sekolah. Pembatasan objek dilakukan yaitu hanya pada pengelolaan pendidikan di tingkat sekolah dasar.

Pelaksanaan Standar Pengelolaan Pendidikan di Sekolah Dasar Kecamatan Ngemplak ... 


\section{METODE}

Penelitian ini menggunakan desain evaluasi model Stake. Stake menekankan adanya dua dasar kegiatan dalam evaluasi, yaitu description dan judgement dan membedakan adanya tiga tahap dalam program pendidikan yaitu context, process dan outcomes. Stake menyatakan bahwa apabila menilai suatu program pendidikan, maka harus melakukan perbandingan yang relatif antara satu program dengan yang lainnya. Dalam model ini antencedent (masukan), transaction (proses) dan outcomes (hasil) data dibandingkan tidak hanya untuk menentukan apakah ada perbedaan antara tujuan dengan keadaan yang sebenarnya, tetapi juga dibandingkan dengan standar yang absolut untuk menilai manfaat program (Farida Yusuf Tayibnapis, 2000:22).

Tempat penelitian ini dilaksanakan di sekolah dasar-sekolah dasar di Kecamatan Ngemplak Kabupaten Sleman. Subjek penelitian adalah keseluruhan wilayah generalisasi yang menjadi perhatian peneliti dalam ruang lingkup dan waktu yang ditentukan, memiliki parameter tertentu dan terukur (Sugiyono, 2013: 297). Populasi dalam penelitian tentang pencapaian standar nasional pendidikan dalam bidang pengelolaan pendidikan dasar di Kecamatan Ngemplak Kabupaten Sleman adalah seluruh kepala sekolah yang berjumlah 25 orang, seluruh guru yang berjumlah 176 orang. Subjek penelitian ini adalah kepala sekolah dan guru dari sekolah dasar yang telah mendapatkan penilaian oleh Badan Akreditasi Nasional tahun 2011 dan tahun 2012.

Variabel dalam penelitian ini ada 5 sub variabel yaitu: Perencanaan program, Pelaksanaan program, Evaluasi, Kepemimpinan, dan Sistem manajemen.

\section{Data, intrumen, dan teknik pengumpulan data}

Pengumpulan data dilakukan dengan 3 cara yaitu angket, observasi dan doku- mentasi, dari ketiga cara tersebut angket adalah alat utama sedangkan observasi dan dokumentasi merupakan pendukung untuk memperkuat data angket.

\section{Angket}

Angket merupakan alat penelitian berupa daftar pertanyaan yang harus dijawab oleh responden. Responden diminta untuk mengisi jawaban dengan memilih salah satu jawaban yang dianggap sesuai dengan pendapat setiap responden. Responden yang diberikan angket adalah kepala sekolah dan guru

\section{Observasi}

Teknik observasi dimaksudkan untuk memperkuat hasil penelitian yang berupa angka-angka dan perhitungan statistik, sehingga hasil yang ditemukan dari penelitian ini benar-benar dapat dipercaya dan obyektif. Dalam observasi peneliti melakukan pengecekan di lapangan mengenai pengelolaan pendidikan di beberapa sekolah di lokasi penelitian. Objek yang diobservasi yaitu pelaksanaan kegiatan belajar mengajar di sekolah, perilaku kepala sekolah dalam memimpin, dan mengawasi pelaksanaan pembelajaran.

\section{Dokumentasi}

Teknik dokumentasi dalam penelitian ini digunakan untuk mendapatkan data yang berhubungan dengan dokumentasi misalnya dokumen visi, misi, kurikulum, struktur organisasi, data personil sekolah dan satuan pelajaran yang dibuat guru serta dokumen penunjang lainnya yang berkaitan dengan fokus penelitian ini. Dokumen merupakan bukti fisik dari kegiatan/program yang dilaksanakan

Instrumen yang digunakan mengumpulkan data yaitu berupa kuesioner, dokumentasi, observasi. Data dikumpulkan dengan cara membagi kuesioner kepada 86 subjek penelitian. 


\section{Validitas dan Reabilitas Instrumen}

Validitas instrumen dilakukan dengan teknik validitas isi dan validitas konstruk. Untuk menjamin tingginya validitas isi, maka semua pertanyaan disusun berdasarkan kajian-kajian teori yang berkaitan dengan permasalahan yang akan diukur, kisi-kisi yang telah disusun dan pengalaman empiris. Supaya instrumen betul-betul memiliki tingkat validitas isi yang tinggi, maka instrumen tersebut telah dikonsultasikan kepada validator dari Universitas Negeri Yogyakarta.

Validitas data juga diuji secara empiris dengan mengujicobakan kepada 9 orang guru SD. Pengujian validitas empiris menggunakan teknik analisis butir, yaitu dengan cara mengkorelasikan skor tiap butir dengan skor totalnya. Analisis butir pada instrumen penelitian ini diuji dengan korelasi Product Moment dari Pearson melalui program SPSS. Seluruh item pertanyaan diambil dari Permendiknas nomor 19 tahun 2007 tentang standar pengelolaan dan instrumen yang digunakan Departemen Pendidikan Nasional untuk menilai kinerja sekolah. Di samping itu, butir-butir instrumen juga telah melalui validasi oleh validator dari Universitas Negeri Yogyakarta dan Dinas Pendidikan Pemuda dan Olahraga Kabupaten Sleman.

Reliabilitas atau kehandalan instrumen, sama artinya dengan kemantapan, konsistensi, keteramalan, dan ketepatan instrumen. Tingkat reliabilitas ditentukan berdasarkan besarnya koefisien reliabilitas yang dimiliki. Semakin tinggi koefisien korelasi, semakin tinggi pula reabilitas instrumen tersebut. Dalam penelitian ini uji reliabilitas dilakukan dengan menggunakan metode Alpha Cronbach. Uji reliabilitas dalam penelitian ini dilakukan dengan menggunakan metode Alpha Cronbach. Apabila didapatkan nilai Cronbach's Alpha kurang dari 0,60 berarti buruk, sekitar 0,70 diterima dan lebih dari atau sama dengan 0,80 adalah baik (Sekaran, 2003:311). Hasil uji coba menunjukkan bahwa harga koefisien Alpha Cronbach sebesar 0,9688 sehingga instrumen reliabel dan termasuk dalam kategori baik karena mempunyai nilai koefisien Alpha dari Cronbach lebih dari 0,8 .

\section{Teknik analisis data}

Analisis data yang digunakan dalam penelitian ini adalah analisis data kuantitatif dilakukan dengan teknik deskriptif yaitu mendeskripsikan tiap-tiap data dari indikator. Data yang telah diolah dari angket yang berhasil dikumpulkan kemudian diprosentase, selanjutnya dideskripsikan dan diambil kesimpulan tentang masing-masing komponen dan indikator berdasarkan kriteria yang telah ditentukan. Pemberian kriteria dari jawaban responden didasarkan pada skor yang diperoleh dari jumlah skor tiap kelompok butir. Jawaban responden dikelompokkan ke dalam empat kategori sesuai dengan variabel. Penentuan kategori tersebut didasarkan pada rerata ideal dan simpangan baku ideal dari rentang skor yang dapat dicapai instrumen. Mean ideal =0,5 (nilai terendah + nilai tertinggi) dan simpangan baku ideal $=1 / 6$ (nilai tertinggi) - (nilai terendah) .

Kriteria penilaian yaitu:

$\mathrm{Mi}+1,8$ Sbi atau lebih $=$ Sangat Baik Dari Mi + 0,6 Sbi sampai Mi + 1,8 Sbi=Baik Dari Mi-0,6Sbi sampai Mi +0,6 Sbi=Cukup Dari Mi-1,8Sbi sampai Mi-0,6Sbi=Kurang

\section{HASIL DAN PEMBAHASAN}

\section{Perencanaan Program Pendidikan Dasar}

Keadaan perencanaan program pendidikan memperlihatkan bahwa 62,78\% responden menilai perencanaan program sudah sangat baik, dan 36,06\% menilai baik. Perencanaan tampak pada Tabel 1. 
Tabel 1. Perencanaan Program Pendidikan Dasar

\begin{tabular}{cccc}
\hline Nilai & \multicolumn{3}{c}{ Kategori Frekuensi Frekuensi } \\
$(\%)$
\end{tabular}

Keadaan perencanaan juga dapat dilihat pada Grafik 1.

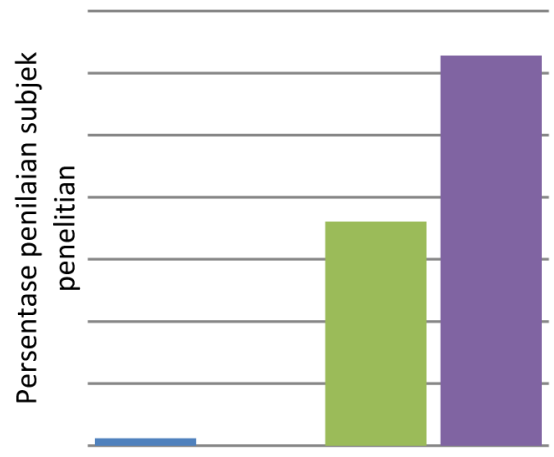

Grafik 1. Perencanaan Program

Perencanaan program pendidikan dasar tampak dari adanya rencana kerja jangka menengah (empat tahunan) dan rencana kerja tahunan yang merupakan perwujudan dari visi, misi dan tujuan penyelenggaraan pendidikan dasar. Berdasarkan studi dokumen di beberapa sekolah yang diteliti, rencana kerja program tahunan disusun sekedar untuk memenuhi formalitas karena tidak memperlihatkan adanya kesinambungan yang jelas antara program jangka menengah dengan program tahunan.

Berdasarkan penilaian atau pendapat responden terhadap kondisi aspek-aspek perencanaan program pendidikan dapat diketahui bahwa perencanaan program pendidikan di sekolah-sekolah dasar di Kecamatan Ngemplak sudah memenuhi standar. Bagaimana kesesuaian perencanaan program pendidikan ini dengan standar yang ditetapkan dapat ditunjukkan dari pendapat responden. Dari jawaban 86 responden atas pertanyaan-pertanyan yang terkait dengan perencanan program pendidikan sejumlah 54 responden $(62,79 \%)$ menyatakan sangat baik, 31 responden $(36,06 \%)$ menyatakan baik dan satu responden $(1,16 \%)$ menyatakan kurang baik.

Dari jawaban seluruh pertanyaan tentang aspek perencanaan program pendidikan bila dirata-rata tiap pertanyaan mendapat nilai 3,9. Berdasarkan ketentuan skor/nilai atas tiap pertanyaan yaitu dari skor 1 sampai 4, nilai tersebut menunjukkan keadaan perencanaan program pendidikan yang tergolong sudah baik dan sedang berproses menuju tingkatan yang lebih baik lagi (sangat baik).

\section{Pelaksanaan Program Pendidikan Dasar}

Pelaksanaan program pendidikan dasar memperlihatkan bahwa $88,37 \%$ responden menilai pelaksanaan program sudah sangat baik, 8,14\% menilai baik, dan ada $3,49 \%$ cukup. Kategori pelaksanaan program seperti tampak pada Tabel 2.

Tabel 2. Pelaksanaan Program Pendidikan Dasar

\begin{tabular}{|c|c|c|c|}
\hline Nilai & Kategori & Frekuensi & $\begin{array}{c}\text { Presentase } \\
(\%)\end{array}$ \\
\hline$X \geq 112,2$ & $\begin{array}{c}\text { Sangat } \\
\text { baik }\end{array}$ & 76 & $88,37 \%$ \\
\hline $\begin{array}{c}92,4<x< \\
112,2\end{array}$ & Baik & 7 & $8,14 \%$ \\
\hline $72,6<x \leq 92,4$ & Cukup & 3 & $3,49 \%$ \\
\hline $51 \leq 72,6$ & $\begin{array}{c}\text { Kurang } \\
\text { baik }\end{array}$ & - & $0 \%$ \\
\hline \multicolumn{3}{|c|}{ Jumlal } & $100 \%$ \\
\hline
\end{tabular}

Keadaan pelaksanaan program pendidikan dasar dapat dilihat pada Grafik 2. 


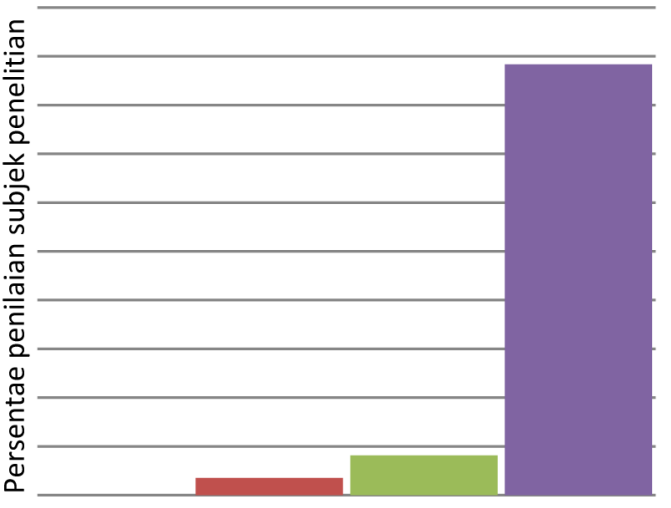

Grafik 2. Pelaksanaan Program

Berdasarkan observasi di beberapa sekolah yang diteliti, pelaksanaan program tampak sudah baik. Hal ini tampak dari sudah adanya pedoman pengelolaan secara tertulis, kegiatan kesiswaan, ada layanan konseling bagi siswa, kegiatan ekstrakurikuler dan non kurikuler, peraturan akademik, pelaksanaan kegiatan pembelajaran, pedoman pengelolaan pembiayaan pendidikan, tata tertib/peraturan sekolah, adanya kegiatan pemeliharaan fasilitas fisik sekolah, dan adanya suasana dan lingkungan belajar di sekolah.

Pelaksanaan progam pendidikan mengacu pada visi, misi serta tujuan sekolah, diwujudkan dengan seluruh kegiatan yang terkait langsung dengan kegiatan pembelajaran di kelas. Hal-hal yang terkait langsung dengan pembelajaran yaitu apakah materi pembelajaran yang diberikan sesuai dengan kurikulum yang ditentukan, apakah pembelajaran diselenggarakan dengan tenaga kependidikan yang memadai, dan dapat melibatkan masyarakat dalam penyediaan sarana prasarana yang dapat menjamin tercapainya standar kompetensi lulusan, kesemuanya itu sebagai inti dari implementasi program pendidikan, termasuk pendidikan di SD-SD di Kecamatan Ngemplak.

Berdasarkan ketentuan skor/nilai atas tiap pertanyaan yaitu dari skor 1 sampai 4, nilai tersebut menunjukkan keadaan pelaksanaan program pendidikan yang tergolong sudah baik dan sedang berproses menuju tingkatan yang lebih baik lagi (sangat baik).

\section{Pengawasan dan Evaluasi Program Pendidikan Dasar}

Pengawasan dan evaluasi program pendidikan dasar memperlihatkan bahwa $50 \%$ responden menilai pengawasan dan evaluasi sudah sangat baik, $41,6 \%$ menilai baik, $6,98 \%$ cukup, dan ada $1,16 \%$ menilai kurang baik. Kategori pengawasan dan evaluasi program seperti tampak pada Tabel 3.

Tabel 3. Pengawasan dan Evaluasi Program

\begin{tabular}{|c|c|c|c|}
\hline Nilai & Kategori & Frekuensi & $\begin{array}{c}\text { Presentase } \\
(\%)\end{array}$ \\
\hline$X \geq 13,6$ & $\begin{array}{l}\text { Sangat } \\
\text { baik }\end{array}$ & 43 & $50 \%$ \\
\hline $11,2<x<13,6$ & Baik & 36 & $41,6 \%$ \\
\hline $8,8<x \leq 11,2$ & Cukup & 6 & $6,98 \%$ \\
\hline $6,4<x \leq 8,8$ & $\begin{array}{c}\text { Kurang } \\
\text { baik }\end{array}$ & 1 & $1,16 \%$ \\
\hline Jumlah & & 86 & $100 \%$ \\
\hline
\end{tabular}

Keadaan pengawasan dapat dilihat pula pada Grafik 3.

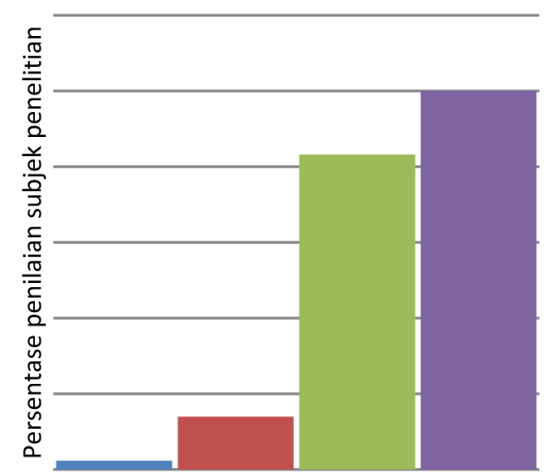

Grafik 3. Pengawasan dan Evaluasi Program

Untuk terciptanya efektivitas proses pembelajaran dituntut adanya pemgawasan dan evaluasi terhadap kegitan pembelajaran. Pelaksanaan pengawasan ini terkait dengan tanggung jawab sekolah sebagai pemberi pelayanan pendidikan kepada 
masyarakat. Masyarakat dan segenap stakeholder menuntut dilaksanakannya pengawasan dalam proses pembelajaran di sekolah-sekolah terkait kepentingnnya terhadap kualitas output.

Dengan pengawasan yang efektif diharapkan proses pembelajaran mulai dari tahap perencanaan hingga evaluasi dapat berjalan sesuai dengan standar aturan yang berlaku atau yang ditetapkan. Pelaksanaan pengawasan direalisasikan dengan berlangsungnya program pengawasan yang menyangkut kinerja tenaga pendidik dan tenaga kependidikan seperti adanya supervisi kelas, evaluasi hasil belajar, termasuk di sini supervisi terhadap kelengkapan administrasi pembelajaran yang harus dikerjakan oleh guru untuk mencapai efektivitas pembelajaran. Mengenai pelaksanaan pengawasan dan evaluasi program pendidikan di sekolah-sekolah dasar di Kecamatan Ngemplak apakah sudah memenuhi standar yang berlaku, hal ini dapat dlihat dari hasil penelitian.

Berdasarkan ketentuan skor/nilai tersebut di atas, menunjukkan keadaan pelaksanaan program pendidikan yang tergolong sudah baik dan sedang berproses menuju tingkatan yang lebih baik lagi (sangat baik).

\section{Kepemimpinan Sekolah Dasar}

Pengawasan dan evaluasi program pendidikan dasar memperlihatkan bahwa $53,4 \%$ responden menilai kepemimpinan kepala sekolah sudah sangat baik, 40,70\% menilai baik, dan 5,81\% cukup. Kategori kepemimpinan sekolah dasar seperti tampak pada Tabel 4 .

Tabel 4. Kepemimpinan Sekolah Dasar

\begin{tabular}{|c|c|c|c|}
\hline Nilai & Kategori & Frekuensi & $\%$ \\
\hline$x \geq 47,6$ & $\begin{array}{c}\text { Sangat } \\
\text { baik }\end{array}$ & 46 & $53,4 \%$ \\
\hline $39,2<x<47,6$ & Baik & 35 & $40,70 \%$ \\
\hline $30,8<x \leq 39,2$ & Cukup & 5 & $5,81 \%$ \\
\hline $22,4<x \leq 30,8$ & $\begin{array}{c}\text { Kurang } \\
\text { baik }\end{array}$ & - & $0 \%$ \\
\hline Jumla & & 86 & $100 \%$ \\
\hline
\end{tabular}

Keadaan kepemimpinan tampak pada Grafik 4.

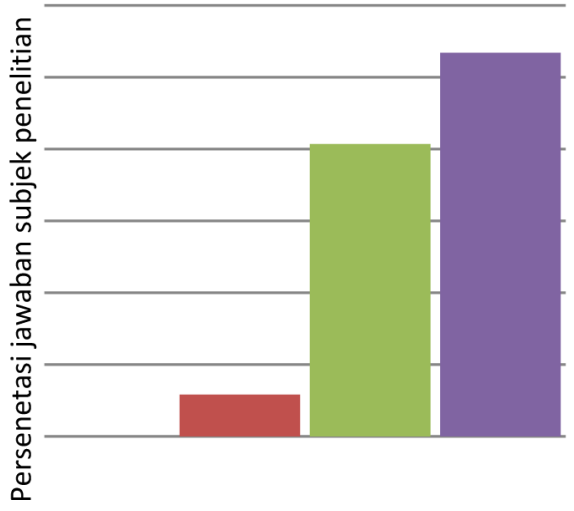

Grafik 4. Kepemimpinan Sekolah Dasar

Pelaksanaan tugas pokok dan fungsi kepala sekolah merupakan inti dari kepemimpinan pendidikan. Sebagai pimpinan lembaga pendidikan, kepala sekolah harus melaksanakan tugas-tugas kepemimpinan terutama untuk memanage sumbersumber daya pendidikan dan menganalisis factor-faktor yang berpengaruh terhadap proses pembelajaran. Selain itu, kemampuan memahami peluang, tantangan, kekuatan dan kelemahan sekolah diperlukan kepala sekolah untuk melakukan pola kepemimpinan yang tepat dalam rangka menjalin komunikasi dengan masyarakat dan mendapatkan partisipasi masyarakat dalam kemajuan penyelenggaraan pendidikan.

Kepemimpinan dengan pola seperti ini sangat diperlukan dalam rangka pengelolaan sekolah yang didasarkan pada kemandirian seperti MBS. Bagaimana pelaksanaan kepemimpinan pendidikan dasar di SD di Kecamatan Ngemplak apakah sudah sesuai dengan standar pengelolaan pendidikan, hal ini dapat dilihat dari hasil penelitian.

Dari jawaban seluruh pertanyaan tentang aspek kepemimpian sekolah dasar tersebut, bila dirata-rata tiap pertanyaan mendapat nilai 3,42. Berdasarkan ketentuan skor/nilai atas tiap pertanyaan yaitu 
dari skor 1 sampai 4, nilai tersebut menunjukkan keadaan pelaksanaan program pendidikan yang tergolong sudah baik dan sedang berproses menuju tingkatan yang lebih baik lagi (sangat baik).

\section{Sistem Informasi Manajemen Pen- didikan Dasar}

Sistem informasi manajemen pendidikan dasar memperlihatkan bahwa 26,74\% responden menilai Sistem informasi manajemen sudah sangat baik, 55,81\% menilai baik, $16,29 \%$ cukup, dan 1,16\% menilai kurang baik. Kategori sistem Informasi manajemen pendidikan dasar tampak pada Tabel 5.

Tabel 5. Sistem Informasi Manajemen Pendidikan Dasar

\begin{tabular}{cccc}
\hline Nilai & \multicolumn{2}{c}{ Kategori Frekuensi Presentase } \\
& & & $(\%)$ \\
\hline $\mathrm{x} \geq 10,2$ & Sangat & 23 & $26,74 \%$ \\
& baik & & \\
$8,4<\mathrm{x}<10,2$ & Baik & 48 & $55,81 \%$ \\
$6,6<\mathrm{x} \leq 8,4$ & Cukup & 14 & $16,29 \%$ \\
$4,8<\mathrm{x} \leq 6,6$ & Kurang & 1 & $1,16 \%$ \\
& baik & & \\
\hline \multicolumn{2}{c}{ Jumlah } & 86 & $100 \%$ \\
\hline
\end{tabular}

Sistem informasi manajemen sangat diperlukan dalam organisasi termasuk dalam organisasi pendidikan. Hal ini dalam rangka meningkatkan kualitas kinerja dan mendukung sistem administrasi pendidikan yang ada.

Dengan meningkatnya kualitas kinerja administrasi yang baik, berarti akan mendukung sistem-sistem yang lain serta meningkatkan program-program baru dalam rangka meningkatkan kualitas pendidikan yang ada di SD se-Kecamatan Ngemplak. Keadaan sistem informasi manajemen menurut penilaian subjek penelitian dapat pula dilihat pada grafik 5 .

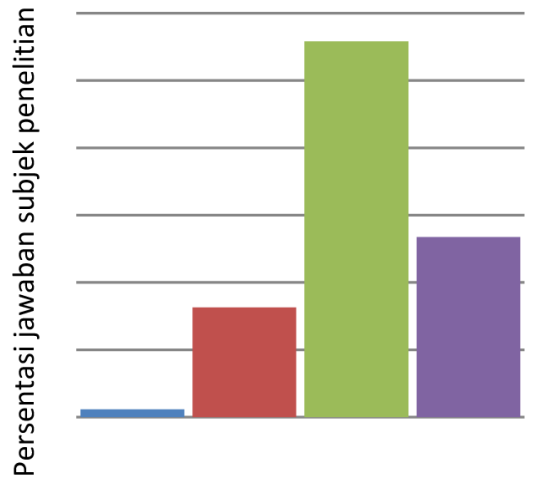

Grafik 5. Sistem Manajemen Informasi

Dengan adanya sistem informasi yang memadai, semua warga sekolah khususnya kepala sekolah, guru maupun staf dapat mengakses informasi mengenai berbagai hal. Baik informasi yang berkaitan dengan sekolah, seperti layanan dan fasilitas sekolah, program unggulan sekolah ataupun informasi yang berkaitan dengan peningkatan kualitas kerja guru. Sistem informasi yang memadai dapat meningkatkan prestise sekolah, karena dengan adanya sistem informasi yang memadai, menunjukkan bahwa sekolah memiliki fasilitas yang mengikuti perkembangan zaman yang berwawasan iptek. Tentunya, adanya sistem informasi yang memadai perlu didukung tenaga ahli yang khusus dalam bidang teknologi dan informasi.

Standar pengelolaan sekolah menuntut diantaranya, sistem informasi manajemen yang memadai. Mengenai bagaimana keadaan sistem informasi manajemen di sekolah-sekolah dasar di kecamatan Ngemplak, hal ini dapat dilihat dari penelitian. Dari jawaban seluruh pertanyaan tentang aspek sistem informasi menejemen tersebut, bila dirata-rata tiap pertanyaan mendapat nilai 3,2. Berdasarkan ketentuan skor/nilai atas tiap pertanyaan yaitu dari skor 1 sampai 4, nilai tersebut menunjukkan keadaan pelaksanaan program pendidikan yang tergolong sudah baik dan sedang berproses menuju tingkatan yang lebih baik lagi (sangat baik). 
Pengelolaan pendidikan dasar secara keseluruhan dapat diketahui dengan merangkum seluruh komponen pengelolaan berikut:

Tabel 6. Pengelolaan Pendidikan Sekolah Dasar

\begin{tabular}{|c|c|c|c|}
\hline $\begin{array}{l}\text { Komponen } \\
\text { pengelolaan }\end{array}$ & $\begin{array}{c}\% \\
\text { Sangat } \\
\text { baik }\end{array}$ & $\begin{array}{c}\% \\
\text { baik }\end{array}$ & $\begin{array}{c}\% \\
\text { Kumu- } \\
\text { latif }\end{array}$ \\
\hline $\begin{array}{l}\text { Perencanaan } \\
\text { Program }\end{array}$ & $62,78 \%$ & $36,06 \%$ & $98 \%$ \\
\hline Pelaksanaan program & $88,37 \%$ & $8,14 \%$ & $96 \%$ \\
\hline $\begin{array}{l}\text { Pengawasan dan } \\
\text { Evaluasi }\end{array}$ & $50 \%$ & $41,6 \%$ & $91 \%$ \\
\hline $\begin{array}{l}\text { Kepemimpinan } \\
\text { Sekolah Dasar }\end{array}$ & $53,4 \%$ & $40,70 \%$ & $94 \%$. \\
\hline $\begin{array}{l}\text { Sistem Manajemen } \\
\text { Informasi pendidikan } \\
\text { dasar }\end{array}$ & $26,74 \%$ & $55,81 \%$ & $82,55 \%$ \\
\hline
\end{tabular}

Tabel 6 memperlihatkan bahwa pengelolaan terbaik tampak pada aspek pelaksanaan program yaitu $88,3 \%$, dilanjutkan dengan perencanaan program $62,78 \%$, kepemimpinan kepala sekolah $53,4 \%$, dan paling rendah pada komponen sistem manajemen informasi pendidikan dasar yaitu $26,74 \%$ ). Dengan demikian pengelolaan pendidikan di sekolah dasar yang paling kurang mendapat perhatian atau masih jauh dari standar nasional pengelolaan pendidikan adalah dalam hal manajemen informasi.

\section{PENUTUP}

Berdasarkan hasil penelitian dan pembahasan dapat disimpulkan, (1) pelaksanaan pengelolaan pendidikan di Sekolah Dasar di Kecamatan Ngemplak pada aspek perencanaan program pendidikan telah memenuhi standar pengelolaan. (2) Pelaksanaan pengelolaan pendidikan di Sekolah Dasar di Kecamatan Ngemplak pada aspek pelaksanaan program pendidikan telah memenuhi standar pengelolaan. (3) Pelaksanaan pengelolaan pendidikan di Sekolah Dasar di Kecamatan Ngem- plak pada aspek pengawasan pendidikan telah memenuhi standar pengelolaan. (4) Pelaksanaan pengelolaan pendidikan di Sekolah Dasar di Kecamatan Ngemplak pada aspek kepemimpinan sekolah dasar telah memenuhi standar pengelolaan. (5) Pelaksanaan pengelolaan pendidikan di Sekolah Dasar di Kecamatan Ngemplak pada aspek sistem informasi menejemen telah memenuhi standar pengelolaan.

Saran penelitian ini (1) diperlukan dukungan bagi sekolah-sekolah yang masih kurang dalam pelaksanaan asas-asas MBS untuk dapat mengoptimalkan pelaksanaan aspek-aspek pegelolaan sekolah agar lebih sesuai dengan standar-standar pengelolaan pendidikan yang berlaku, (2) diperlukan langkah-langkah untuk mempertahankan dan meningkatkan kualitas pengelolaan pendidikan yang sudah sesuai dengan standar pengelolaan yang berlaku untuk semakin meningkatkan kualitas pendidikan.

\section{DAFTAR PUSTAKA}

Arifin, Zaenal. (2009). Evaluasi Pembelajaran. Bandung: Rosdakarya.

Becket, N. \& Brookes, M. (2008). Quality Management Practice in Higher Education - What Quality Are We Actually Enhancing? Dimuat dalam Journal of Hospitality, Leisure, Sport and Tourism Education, Vol. 7, No. 1, hal. 40 - 54.

BNSP. (2007). Peraturan Menteri Pendidikan Nasional Republik Indonesia Nomor 19 Tahun 2007 tentang Standar Pengelolaan Pendidikan oleh Satuan Pendidikan Dasar dan Menengah. Jakarta: BNSP.

Boudreau, M. (1997). Human Resource Management. London: Irwin.

Bush, T. (2007). Educational Leadership and Management: Theory, Policy, and Practice, dimuat dalam South African Journal of Education, Vol. 27 (3), hal 391-406.

Caldwell, Brian J. (2005). School Based Management. Paris: The International Institute for Educational Planning 
(IIEP) \& The International Academy of Education (IAE).

Fattah, Nanang. (2004). Landasan Manajemen Pendidikan. Bandung: PT. Remaja Rosdakarya.

Handoko, Hani. (2003). Manajemen. Yogyakarta: BPFE.

Harris, A. \& Spillane J. (2008). Distributed Leadership through the Looking Glass. Dimuat dalam Management in Education 2008, Vol. 22, No. 1, hal 31-34.

Hasibuan, Malayu, S.P. (2009). Manajemen Sumber Daya Manusia. Jakarta: Bumi Aksara.

Jalaluddin. (2011). Filsafat Pendidikan Islam: Telaah Sejarah dan Pemikirannya. Jakarta: Kalam Mulia.

Mardapi, Djemari. (2008). Teknik Penyusunan Instrumen Tes dan Nontes. Yogyakarta: Mitra Cendekia.

Mulyasa, E., (2004). Manajemen Berbasis Sekolah. Bandung: Rosdakarya.

Ngalim Purwanto. (2010). Evaluasi Pengajaran. Bandung: Rosda Karya.

Robbins, S. \& Judge T.A. (2007). Organizational Behavior, 12th Ed. New Jersey: Pearson Educational International.

Rohayati, Eti. (2005). Sistem Informasi Manajemen Pendidikan. Jakarta: PT Bumi Aksara.
Sasmedi, Darwis. (2008). Penerapan Manajemen Berbasis Sekolah (MBS) di Satuan Pendidikan. Diakses dari http:// www.lpm psulsel.net/v2/index. php?optionswara\&It, tanggal 12 Juli 2012.

Sekaran, U. (2003). Research Method for Bussiness a Skill Building Approach, 4th Ed. New Jersey: John Wiley \& Son.

Soekanto, Soerjono. (2002). Sosiologi: Suatu Pengantar. Jakarta: Raja Grafindo Persada.

Sugiyono. (2006). Metode Penelitian Pendidikan (Pendekatan Kuantitatif, Kualitatifdan $R \mathcal{E D})$. Bandung: CV. Alfabeta.

Tayibnapis, Farida Yusuf. (2000). Evaluasi Program. Jakarta: PT. Rineka Cipta.

Umaedi. (2000). Manajemen Peningkatan Mutu Berbasis Sekolah. Makalah disampaikan dalam Konvensi Nasional Pendidikan Indonesia. Jakarta: Dikbud.

Usman, Husaini. (2006). Manajemen: Teori, Praktik, dan Riset Pendidikan. Jakarta: Bumi Aksara.

Wahyudi. (2009). Kepemimpinan Kepala Sekolah. Jakarta: Alfabeta.

Wijaya, Muksin. (2005). Kepemimpinan Transformasional di Sekolah dalam Meningkatkan Outcomes Peserta Didik dimuat dalam Jurnal Pendidikan Penabur, No.05/Th.IV/ Desember 2005, hal 118-127. 